\title{
Sarah Piram. " S'approprier un modèle français en Iran ? L'architecte André Godard (1881-1965) et la conception des musées iraniens »
}

\section{Rémy Boucharlat}

\author{
(2) OpenEdition \\ Journals \\ Édition électronique \\ URL : http://journals.openedition.org/abstractairanica/47848 \\ DOI : 10.4000/abstractairanica.47848 \\ ISBN : 1961-960X \\ ISSN : 1961-960X \\ Éditeur : \\ CNRS (UMR 7528 Mondes iraniens et indiens), Éditions de l'IFRI
}

\section{Référence électronique}

Rémy Boucharlat, « Sarah Piram. « S'approprier un modèle français en Iran ? L'architecte André Godard (1881-1965) et la conception des musées iraniens » », Abstracta Iranica [En ligne], Volume 40-41 | 2019, document 1, mis en ligne le 15 juillet 2019, consulté le 22 avril 2021. URL : http:// journals.openedition.org/abstractairanica/47848; DOI : https://doi.org/10.4000/abstractairanica. 47848

Ce document a été généré automatiquement le 22 avril 2021.

Tous droits réservés 


\title{
Sarah Piram. « S’approprier un modèle français en Iran? L'architecte André Godard (1881-1965) et la conception des musées iraniens »
}

\author{
Rémy Boucharlat
}

\section{RÉFÉRENCE}

Sarah Piram. « S'approprier un modèle français en Iran ? L'architecte André Godard (1881-1965) et la conception des musées iraniens ", Les Cahiers de l'Ecole du Louvre [en ligne] 11, 2017, 17 p. http://cel.revues.org/825; DOI : 104D000/cel.825

1 Le musée du Louvre conserve les archives de l'architecte André Godard, des milliers de documents, écrits, dessins et photographies, qui concernent principalement l'Iran où Godard fut directeur des services archéologiques, et des Antiquités et des Musées de 1928 à 1960. Ces fonctions confiées à un Français étaient, à l'origine, une compensation diplomatique de l'abolition du monopole français sur les fouilles archéologiques dans tout l'Iran octroyé en 1897. A. Godard resta en Iran, construisant le musée national actuel inauguré en 1939 et, plus tard, lançant la construction de musées dans les grandes villes régionales. Il fut aussi l'architecte de tombeaux de poètes persans (Ferdowsī, Hāfez). Pour ces monuments, il fut partisan d'une architecture moderne mais inspirée de l'architecture traditionnelle iranienne; il s'éloigna en revanche de ce concept pour la construction de la Faculté des beaux-arts de l'université de Téhéran. Il publia largement sur les monuments d'époque islamique. En trente ans, A. Godard forma des générations d'architectes et de conservateurs du patrimoine en Iran. 
2 L'A donne ici un bilan nuancé de l'œuvre et de l'influence de Godard qui n'ont pas assez été évaluées et critiquées, comme ce fut le cas pour E. Herzfeld, acteur tout aussi important dans le patrimoine iranien dans les trois premières décennies du XXe siècle.

\section{AUTEURS}

\section{RÉMY BOUCHARLAT}

UMR 5133 CNRS-Université de Lyon 